\title{
EFFECT OF AUDIT FEE, AUDIT TENURE AND ROTATION KAP ON AUDIT QUALITY IN INDONESIA STOCK EXCHANGE
}

(Study at Manufacturing Companies Listed on the Stock Exchange Years 2012-2016)

\author{
Hardini Oning Arvyanti ${ }^{1}$, Iwan Budiyono ${ }^{2}$ \\ 1,2Politeknik Negeri Semarang, Semarang \\ $\checkmark$ hardinioning16@gmail.com
}

\begin{abstract}
This study aimed to examine the effect of audit fees, audit tenure and rotation $K A P$. Groundedon literature reviews, alleged that the variable fee audit, audit tenure and KAP rotation affects the quality of auditors. The data used are the audited financial statements of companies listed on the Indonesia Stock Exchange. Testing is done by regression. Statistical test results proved that: Fee audit significant effect on audit quality, while the rotation of audit tenure and no significant effect on audit quality. The first possibility, due to the reluctance of market participants to explore further whether the auditor who issued the opinion on the audited financial statements really never experienced rotation or not. The second possibility, market participants also never pay attention to whether the financial statements audited by an auditor who has a certain reputation or not. There are various things that need to be considered for future research. Basically market players in Indonesia are mostly only consider the capital gain, so it is less likely to use fundamental analysis (financial statements) as consideration action to sell or buy shares. If the market does not consider it exhibited significantly on fundamental analysis, could also be said the market actually pay less attention to the audited results (auditor's opinion).
\end{abstract}

Keywords : quality audit, audit fees, audit tenure, rotation $K A P$.

\section{LATAR BELAKANG}

Kualitas audit sangatlah penting karena audit yang berkualitas dapat menjaga kepercayaan, iklim investasi yang sehat dan transparansi ekonomi di setiap negara. Kualitas audit yang handal dapat mendorong pengambilan keputusan bagi pelaku usaha, pemerintah dan stakeholders lain(Langgeng,2018).

Persaingan didalam dunia usaha dewasa ini semakin ketat, termasuk persaingan dalam bisnis pelayanan jasa akuntan publik. Sejalan dengan perkembangan perusahaan go public di Indonesia mengalami kemajuan yang pesat, perkembangan ini mengakibatkan permintaan akan audit laporan keuangan yang meningkat. Sehingga unntuk dapat bertahan ditengah persaingan yang ketat, khususnya dibidang bisnis pelayanan jasa akuntan publik harus dapat menghimpun klien sebanyak mungkin dan mendapatkan kepercayaan dari masyarakat luas, oleh karena itu menuntut para auditor untuk tetap memiliki kualitas audit yang baik (Putra, 2013).

De Angelo (1981) mendefinisikan kualitas audit merupakan probabilitas bahwa auditor akan menemukan dan melaporkan pelanggaran pada sistem akuntansi klien. Hasil kualitas audit digunakan untuk meningkatkan kredibilitas laporan keuangan pengguna informasi akuntansi sehingga dapat mengurangi risiko informasi yang tidak kredibel informasi dalam laporan keuangan bagi pengguna laporan keuangan khususnya investor (Mgbame, et al. 2012). 
Salah satu faktor eksternal yang mempengaruhi kualitas audit adalah fee audit. Chi et al (2005) menyatakan bahwa lamanya hubungan auditor dengan kliennya akan mempengaruhi independensi auditor karena objektivitas menurun. Pembatasan lamanya jangka waktu auditor melakukan pemeriksaan terhadap perusahaan klien diharapkan supaya tidak terjadi eskalasi komitmen auditor terhadap penyimpangan yang dilakukan oleh klien(Andriani, dkk.2017).

Fee audit menjelaskan jumlah yang ditagih oleh auditor untuk penugasan auditnya. Jumlah yang ditagih oleh auditor berdasarkan pengerjaan yang bertujuan untuk memberikan opini atas kewajaran laporan keuangan perusahaan. Biaya audit ditentukan dari kompleksitas jasa, risiko penugasan, struktur biaya akuntan publik, tingkat keahlian dan pertimbangan profesional lain. Oleh karena itu, biaya audit berpengaruh signifikan terhadap pemilihan auditor eksternal yang berkualitas (Abdul-Rahman et al., 2017; Tobi et al., 2016; Yuniarti, 2011).

Penelitian yang dilakukan oleh Yuniarti (2011) membuktikan bahwa biaya audit berpengaruh secara signifikan terhadap kualitas audit. Biaya yang lebih tinggi akan meningkatkan kualitas audit, karena biaya audit yang diperoleh dalam satu tahun dan estimasi biaya operasional yang dibutuhkan untuk melaksanakan proses audit dapat meningkatkan kualitas audit. Gammal (2012) membuktikan bahwa perusahaan multinasional dan bank-bank di Lebanon lebih memilih untuk membayar biaya audit yang bernominal besar dengan alasan yaitu mereka lebih mencari auditor yang dapat menghasilkan laporan audit yang berkualitas.

Audit tenure adalah periode penugasan yang disetujui antara auditor dengan klien (Hartadi, 2009). Menurut Ghosh dan Moon (2005) menyatakan bahwa kualitas audit dapat meningkat sesuai dengan peningkatan audit tenure. Oleh karena itu, audit tenure berpengaruh signifikan terhadap pemilihan auditor eksternal yang berkualitas (Geiger \& Raghunandan, 2002; Chen, Lin, \& Lin, 2008; Abdul-Rahman et al., 2017; Tobi et al., 2016).

Hamid (2013) berpendapat bahwa dengan masa tenure yang singkat dimana saat auditor mendapatkan klien baru, membutuhkan tambahan waktu bagi auditor dalam memahami klien dan lingkungan bisnisnya. Masa tenure yang singkat mengakibatkan perolehan informasi berupa data dan bukti-bukti menjadi terbatas sehingga jika terdapat data yang salah atau data yang sengaja dihilangkan oleh manajer sulit ditemukan (Andriani dan Nursiam,2017).

Penelitian yang dilakukan oleh Giri (2010) membuktikan bahwa variabel audit tenure berpengaruh negatif dan signifikan terhadap variabel kualitas audit. Siregar, dkk. (2012) menemukan bukti bahwa masa perikatan (audit tenure) yang lama dapat mempengaruhi rendahnya kualitas audit sebelum rotasi mandatory auditor diterapkan, sebaliknya setelah rotasi mandatory auditor diterapkan masa perikatan (audit tenure) yang lama meningkatkan kualitas audit.

Di Indonesia, dalam melaksanakan tugasnya, auditor dipandu oleh standar audit yang telah ditetapkan oleh Ikatan Akuntan Publik Indonesia (IAPI) menjaga kualitas audit. Standar audit terdiri dari umum standar, standar kerja lapangan, dan standar pelaporan. Selain itu, akuntan publik juga harus mematuhinya Kode Etik yang ditetapkan oleh IAPI. Prinsip dasar etika profesional terdiri dari independensi, integritas, dan objektivitas. 
Menurut standar audit dan kode etik Profesi Akuntan Publik, akuntan publik perlu untuk mempertahankan independensinya. Auditor yang independen dalam menjalankan tugasnya harus netral dan tidak memikul memihak pihak mana pun untuk menghindari konflik kepentingan. Seorang akuntan publik harus menjaga independensi dalam pikirannya dan penampilan (Arens, Penatua \& Beasley, 2012; IAPI, 2011).

Giri (2010) menyatakan bahwa KAP bereputasi menjelaskan adanya sikap independensi auditor dalam melaksanakan tugas audit. KAP besar identik dengan KAP bereputasi tinggi, dalam hal ini menunjukkan kemampuan auditor untuk bersikap independen dalam melaksanakan audit secara profesional sebab KAP menjadi kurang tergantung secara ekonomi kepada klien.

Penelitian yang dilakukan oleh Djamil (2000) mengatakan bahwa terdapat tujuh faktor yang mempengaruhi kualitas audit. Faktor-faktor ini adalah masa audit, jumlah klien, kesehatan keuangan klien, keberadaan pihak ketiga pihak untuk meninjau laporan audit, independensi auditor, tingkat biaya audit, dan tingkat perencanaan audit. Hal yang sama juga disampaikan oleh Widhiyani (2014) yang menemukan bahwa Independensi Auditor berpengaruh positif terhadap Kualitas Audit serta pada penelitian Winda dan Sofie (2014) juga menemukan hal yang sama yaitu Independensi Auditor berpengaruh positif terhadap Kualitas Audit. Namun penelitian yang dilakukan Handayani (2014) berbeda dan menemukan bahwa Independensi Auditor tidak berpengaruh terhadap Kualitas Audit.

Menurut penelitian yang dilakukan Giri (2010) menemukan bukti bahwa KAP yang berafiliasi dengan KAP international berpengaruh terhadap kualitas audit, sedangkan dalam penelitian Hartadi (2012) menemukan bukti bahwa reputasi auditor tidak berpengaruh signifikan terhadap kualitas audit.

\section{Fee Audit berpengaruh signifikan terhadap Kualitas Audit}

Penentuan Audit fee ditentukan oleh besar kecilnya perusahaan yang diaudit (client size), resiko audit (atas dasar current ratio, quick ratio, D/E, Litigation risk), dan kompleksitas Audit (Subsidiares foreign listed).Selain ukuran perusahaan, penentuan honorarim audit juga dapat dilihat berdasarkan struktur biaya KAP yang bersangkutan, tingkat resiko yang mungkin terjadi, kompleksitas tugas yang diberikan, dan tingkat keahlian yang diperlukan (Muthe, 2018).

Menurut Pratistha dan Widhiyani (2014) auditor dengan fee yang tinggi akan melakukan audit lebih luas dan mendalam terhadap perusahaan klien sehingga kemungkinan kejanggalan-kejanggalan yang ada pada laporan keuangan klien dapat terdeteksi.

Penelitian yang dilakukan oleh Munthe (2018) menunjukkan bahwa Fee Audit berpengaruh secara signifikan dan positif terhadap kualitas audit. Hal ini menunjukan bahwa semakin tinggi fee / honorarium yang diterima menurut batas wajar sesuai peraturan yang telah ditetapkan dalam pelaksanaan penugasannya maka kualitas audit yang dihasilkan akan meningkat. Hal serupa juga terjadi pada penelitian yang dilakukan oleh Rahmina dan Agoes (2014) bahwa Fee Audit secara parsial berpengaruh positif dan signifikan terhadap kualitas audit. Dengan demikian hipotesis yang diajukan:

$\mathrm{H}_{1}$ : fee audit berpengaruh positif terhadap kualitas audit. 


\section{Audit Tenure berpengaruh signifikan terhadap Kualitas Audit}

Audit tenure dapat mempengaruhi independensi dan kualitas audit. Masa perikatan (tenure) audit dapat menciptakan kedekatan antara auditor dengan kliennya. Hal tersebut dapat membahayakan sikap independensi auditor yang berakibat pada penurunan kualitas audit. Penelitian oleh Prasetia dan Rozali (2016), menemukan bukti bahwa audit tenure berpengaruh negatif terhadap kualitas audit. Semakin lama auditor KAP mengadakan perikatan audit terhadap kliennya menyebabkan berkurangnya kualitas auditnya. Hal ini disebabkan oleh semakin lamanya masa perikatan auditor akan memiliki hubungan yang terlalu dekat dan dapat menurunkan independensi auditor dan mengurangi profesionalisme kerja dari auditor tersebut, sehingga hasil audit rendah. Sedangkan Pertiwi, dkk (2016) mengatakan bahwa audit tenure tidak berpengaruh terhadap kualitas audit.

Permana (2012) yang menyatakan bahwa audit tenure tidak berpengaruh terhadap kualitas audit. Menurut Hartadi (2012) hal ini disebabkan karena pasar sebenarnya tidak terlalu peduli apakah auditor yang menyatakan opini pada laporan keuangan tahunan tersebut pernah dirotasi atau tidak. Penelitian yang dilakukan Andriani (2017) juga menyatakan bahwa audit tenure tidak berpengaruh signifikan terhadap kualitas audit. Dengan demikian hipotesis yang diajukan:

$\mathrm{H}_{2}$ : audit tenure berpengaruh signifikan terhadap kualitas audit.

\section{Rotasi KAP berpengaruh signifikan terhadap Kualitas Audit}

Kewajiban rotasi dalam perspektif teori agensi dimana teori ini menggambarkan keberadaan perusahaan. Teori perusahaan ini pada dasarnya bertujuan untuk menjawab pertanyaan mengenai : keberadaan perusahaan, batas antara perusahaan dengan pasar, struktur organisasi perusahaan, dan heterogenitas tindakan perusahaan dalam kinerja perusahaan tersebut. Untuk meningkatkan tingkat kepercayaan investor maupun pengguna laporan keuangan, perusahaan berusaha meningkatkan laporan keuangan auditan yang berkualitas pula. Oleh karena itu, perusahaan melakukan rotation audit partner untuk mendapatkan kepercayaan dari pengguna laporan keuangan.Temuan penelitian yang dilakukan oleh Mgbame, et al (2012) menunjukkan bahwa terdapat hubungan yang signifikan secara statistik antara rotasi wajib kantor akuntan publik dengan kualitas audit yang terkait dengan laporan auditan.

Penelitian yang dilakukan oleh Siregar, dkk. (2012) menemukan bukti bahwa sebelum adanya peraturan mengenai rotasi mandatory auditor, audit partner rotation berpengaruh negatif, tetapi ketika adanya peraturan mengenai audit firm rotation menunjukkan pengaruh positif. Penelitian Firth et al. (2012) menunjukkan bahwa rotasi mandatory audit partner berpengaruh signifikan. Era pasca - Enron ini telah menjadi perhatian bagi perkembangan bisnis akuntan publik yang memperhatikan sikap independensi dan kualitas yang dihasilkan oleh seorang auditor dari sebuah KAP. Sehingga para legislator, regulator, dan badan-badan profesional telah setuju dengan adanya rotasi wajib auditor untuk menjaga independensi auditor. Dengan demikian hipotesis yang diajukan:

$\mathrm{H}_{3}$ : rotasi auditor berpengaruh signifikan terhadap kualitas audit. 


\section{TEORI DAN METODE}

\subsection{Variabel Penelitian}

Penelitian ini mengacu pada penelitian yang dilakukan oleh Mgbame (2012) mengemukakan bahwa kualitas audit merupakan sesuatu yang abstrak sehingga sulit untuk diukur dan hanya dapat dirasakan oleh para pengguna jasa audit, sehingga saat ini tidak ada definisi yang jelas mengenai pengukuran kualitas audit tersebut. Dalam penelitian ini digunakan proksi ukuran Kantor Akuntan Publik sebagai pengukuran kualitas audit yaitu dengan menguji secara terpisah terhadap perusahaan sampel yang merupakan klien KAP Big Four dan klien KAP Non Big Four. Penelitian ini mengacu pada penelitian yang dilakukan oleh Rizqiasih (2010) yaitu data tentang fee audit diproksikan oleh akun professional fees yang terdapat dalam laporan keuangan pada perusahaan manufaktur yang terdaftar di Bursa Efek Indonesia (BEI), yang selanjutnya variabel fee audit ini diukur dengan menggunakan logaritma natural dari data atas akun professional fees. Audit tenure dalam penelitian ini mengacu pada penelitian yang dilakukan oleh Werastuti (2013) yaitu dengan menggunakan skala interval sesuai dengan lamanya hubungan auditor dari KAP dengan perusahaan. Audit Tenure diukur dengan cara menghitung jumlah tahun perikatan dimana auditor dari KAP yang sama melakukan perikatan audit terhadap auditee, tahun pertama perikatan dimulai dengan angka 1 dan ditambah dengan satu untuk tahun-tahun berikutnya. variabel rotasi audit mengacu pada penelitian yang dilakukan oleh Siregar (2011) yaitu rotasi audit diukur dengan menggunakan variabel dummy yaitu nilai 1 jika terjadi rotasi auditor; nilai 0 jika tidak terjadi rotasi auditor.

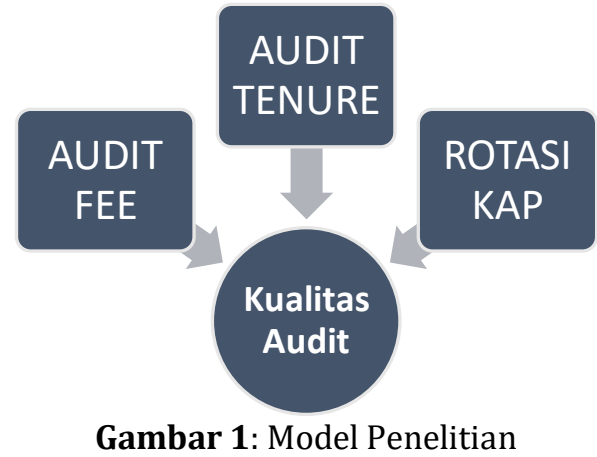

\subsection{Metode Penelitian}

Penelitian ini dilakukan dengan menggunakan model regresi logistik karena variabel dependen dalam penelitian ini bersifat dummy. Pengujian hipotesis juga menggunakan analisis regresi logistik (logistic regression). Menurut Ghozali (2013) regresi logistik hampir sama dengan analisis diskriminan yaitu untuk menguji apakah probabilitas terjadinya variabel terikat dapat diprediksi dengan variabel bebasnya. Dalam analisis regresi logistik tidak memerlukan uji asumsi multivariate normal distribution karena variabel bebas merupakan campuran antara variabel kontinyu (metrik) dan kategorial (non-metrik).

Tahapan analisis regresi logistik (logistic regression) diantaranya dilakukan pengujian kelayakan model regresi (Goodness of Fit Test), menilai model fit (Overall Model Fit), Nagel Karke R2, uji regresi. Metode analisis data yang digunakan untuk menguji hipotesis dalam penelitian ini adalah statistik deskriptif yang digunakan untuk memberikan gambaran mengenai variabel-variabel dalam penelitian ini. 


\subsection{Populasi dan Sampel}

Populasi yang digunakan dalam penelitian ini adalah perusahaan manufaktur yang terdaftar di Bursa Efek Indonesia pada tahun 2014 sampai tahun 2016. Pengambilan sampel dalam penelitian ini menggunakan purposive sampling method. Sampel ditentukan atas dasar kesesuaian karakteristik dan kriteria tertentu. Kriteria sampel pada penelitian ini adalah sebagai berikut:

1. Perusahaan manufaktur yang terdaftar di Bursa Efek Indonesia pada tahun 20142016.

2. Perusahaan manufaktur yang telah menerbitkan Laporan tahunan (Annual Report) dan Laporan Keuangan yang telah diaudit oleh auditor independent selama tahun penelitian tetapi tidak dapat diakses melalui website BEI (www.idx.co.id).

3. Perusahaan mencantumkan akun professional fees dalam laporan keuangan tahunan.

4. Perusahaan menyajikan informasi mengenai total asset dalam laporan keuangan auditan.

5. Selama periode penelitian, perusahaan (auditee) tidak mengalami delisting dari BEI.

\section{HASIL DAN PEMBAHASAN}

\subsection{Hasil Analisis Data}

Populasi dalam penelitian ini adalah seluruh perusahaan manufaktur yang sahamnya terdaftar di Bursa Efek Indonesia (BEI) tahun 2014-2016. Teknik pemilihan sampel yang digunakan adalah purposive sampling. Setelah dilakukan seleksi pemilihan sampel sesuai kriteria yang telah ditentukan maka diperoleh 49 perusahaan manufaktur yang memenuhi kriteria sampel selama periode penelitian. Sedangkan proses pengambilan sampel dapat dilihat pada tabel 4.1:

Tabel 4.1.

Kriteria Pengambilan Sampel Penelitian

\begin{tabular}{|c|c|c|}
\hline No & Keterangan & Jumlah \\
\hline 1 & $\begin{array}{l}\text { Perurasahaan manufaktur } \\
\text { yang terdaftar di Bursa Efek } \\
\text { Indonesia (BEI) 2014-2016. }\end{array}$ & 141 \\
\hline 2 & $\begin{array}{l}\text { Perusahaan manufaktur yang } \\
\text { telah menerbitkan Laporan } \\
\text { tahunan (Annual Report) dan } \\
\text { Laporan Keuangan yang telah } \\
\text { diaudit oleh auditor } \\
\text { independent selama tahun } \\
\text { penelitian tetapi tidak dapat } \\
\text { diakses melalui website BEI } \\
\text { (www.idx.co.id). }\end{array}$ & (12) \\
\hline 3 & $\begin{array}{lr}\text { Perusahaan } & \text { tidak } \\
\text { mencantumkan } & \text { akun } \\
\text { professional fees dalam } \\
\text { laporan keuangan tahunan. }\end{array}$ & $(72)$ \\
\hline 4 & $\begin{array}{l}\text { Perusahaan menyajikan } \\
\text { informasi mengenai total } \\
\text { asset dalam laporan keuangan } \\
\text { auditan. }\end{array}$ & (0) \\
\hline 5 & $\begin{array}{l}\text { Selama periode penelitian, } \\
\text { perusahaan } \\
\text { mengalami delisting dari BEI }\end{array}$ & (8) \\
\hline & Jumlah Perusahaan Sampel & 49 \\
\hline
\end{tabular}




\section{Analisis Statistik Deskriptif}

Analisis statistik deskriptif digunakan untuk memberikan gambaran atau deskripsi suatu data. Dalam penelitian ini analisis statistik deskriptif dilihat menggunakan nilai minimum, nilai maksimum, rata-rata dan standar deviasi.

Hasil analisis statistik deskriptif dalam penelitian ini dapat dilihat dalam table $4.2 \mathrm{di}$ bawah ini:

Tabel 4.2.

Hasil Analisis Statistik Deskriptif

\begin{tabular}{|c|c|c|c|c|c|}
\hline & $\mathrm{N}$ & Minimum & Maximum & Mean & Std.Deviation \\
\hline Kualitas Audit & 245 &, 00 & 1,00 & 5551 &, 49797 \\
\hline Fee Audit & 245 & 17,08 & 26,00 & 21,6606 & 1,84814 \\
\hline Audit Tenure & 245 & 1,00 & 5,00 & 2,6980 & 1,40498 \\
\hline Rotasi KAP & 245 &, 00 & 1,00 &, 0735 &, 26144 \\
\hline $\begin{array}{c}\text { Valid N } \\
\text { (listwise) }\end{array}$ & 245 & & & & \\
\hline
\end{tabular}

Dari hasil analisis deskriptif pada tabel diatas, maka kesimpulan yang dapat diambil adalah sebagai berikut:

1. Nilai minimum kualitas audit adalah sebesar 0 yang berarti bahwa perusahaan tersebut tidak menggunakan KAP Big Four, sedangkan nilai maksimum kualitas audit adalah sebesar 1 yang berarti bahwa perusahaan tersebut mempunyai menggunakan KAP Big Four. Nilai rata-rata kualitas audit tahun 2012-2016 adalah sebesar 0,5551 dengan standar deviasi sebesar 0,49797. Nilai rata-rata tersebut diartikan bahwa jumlah perusahaan yang menggunakan KAP Big Four adalah sebesar 55,51\%. Nilai standar devisasi sebesar 0,49797 yang berarti bahwa tingkat ukuran penyebaran data variabel kualitas audit adalah sebesar 0,49797.

2. Nilai minimum fee audit sebesar 17,08 yang diperoleh PT Keramik Alamsari Intisari Tbk yang berarti bahwa perusahaan tersebut mempunyai fee audit terendah sedangkan nilai maksimum fee audit sebesar 26,00 yang diperoleh PT Indofood Sukses Makmur Tbk berarti bahwa perusahaan tersebut mempunyai mempunyai fee audit tertinggi diantara perusahaan sampel. Nilai rata-rata fee audit tahun 2012-2016 adalah sebesar 21,6606 dengan standar deviasi sebesar 1,84818. Nilai rata-rata fee audit sebesar 21,6606, nilai tersebut dapat diartikan bahwa besarnya biaya yang dikeluarkan untuk audit adalah sebesar 21,6606. Nilai standar deviasi sebesar 1,84818 lebih kecil dari nilai rata-rata, sehingga dapat disimpulkan data variabel kualitas audit bersifat homogen.

3. Nilai minimum tenure audit sebesar 1 yang berarti bahwa perusahaan tersebut mempunyai tenure audit terendah sedangkan nilai maksimum tenure audit sebesar 5 yang berarti bahwa perusahaan tersebut mempunyai mempunyai tenure audit tertinggi diantara perusahaan sampel. Nilai rata-rata tenure audit tahun 20122016 adalah sebesar 2,6980 dengan standar deviasi sebesar 1,40498. Nilai ratarata tenure audit sebesar 2,6980, nilai tersebut dapat diartikan bahwa masa perikatan audit perusahaan sampel adalah sebesar 2,6980 atau 3 tahun. Nilai standar deviasi sebesar 1,40498 lebih kecil dari nilai rata-rata, sehingga dapat disimpulkan data variabel tenure audit bersifat homogen.

4. Nilai minimum rotasi KAP sebesar 0 yang yang berarti bahwa perusahaan tersebut tidak melakukan pergantian auditor sedangkan nilai maksimum rotasi KAP sebesar 1 yang berarti bahwa perusahaan tersebut tidak melakukan pergantian 
auditor. Nilai rata-rata rotasi KAP perusahaan tahun 2012-2016 adalah sebesar 0,0735 atau dengan standar deviasi sebesar 0,26144 . Nilai rata-rata rotasi KAP sebesar 0,0735, nilai tersebut dapat diartikan bahwa jumlah perusahaan yang melakukan pergantian KAP adalah sebesar 7,35\%. Nilai standar deviasi sebesar 0,26144 lebih besar dari nilai rata-rata, sehingga dapat disimpulkan data variabel rotasi KAP bersifat homogen.

\section{Analisis Regresi Logistik}

1. Hosmer and Lemeshow's Goodness of Fit Test

Tabel 4.3.

Hasil Uji Hosmer dan Lemeshow

\begin{tabular}{|c|c|c|c|}
\hline Step & Chisquare & $\mathrm{df}$ & Sig \\
\hline 1 & 11.669 & 8 & .167 \\
\hline
\end{tabular}

Berdasarkan Tabel 4.3.ditunjukkan bahwa nilai dari hosmer and lemeshow goodness of fit test adalah chisquare sebesar 11669 dan signifikansi 0.167 yang nilainya diatas 0.05 . Maka HO diterima yang berarti bahwa model mampu memprediksi nilai observasinya atau dapat dikatakan model dapat dikatakan model diterima karena sesuai dengan data observasinya (Ghozali, 2011).

2. Overall Fit Model

Tabel 4.4.

Overal Model Fit Test

\begin{tabular}{|l|l|}
\hline $\begin{array}{l}\text {-2 Log Likelihood awal } \\
\text { (block Number = 0) }\end{array}$ & $\begin{array}{l}-\mathbf{2} \text { Log Likelihood } \\
\text { Block Number = 1 }\end{array}$ \\
\hline 336.661 & 267.659 \\
\hline
\end{tabular}

Berdasarkan Tabel 4.4 menunjukkan uji kelayakan dengan memperhatikan angka pada -2 Log Likelihood Block Number $=0$ dan -2 Log Likelihood Block Number $=1$. Pada tabel tersebut terlihat bahwa angka awal -2 Log Likelihood Block Number $=0$ adalah 336,661 sedangkan angka -2 Log Likelihood Block Number $=1$ adalah 267,659 .

Dari Tabel 4.4. tersebut ternyata overall model fit pada -2 Log Likelihood Block Number $=0$ menunjukkan adanya penurunan pada -2 Log Likelihood Block Number $=1$. Penurunan likelihood ini menunjukkan model regresi yang lebih baik atau dengan kata lain model yang dihipotesiskan fit dengan data.

3. Nilai Nagel Karke R Square

Tabel 4.5 .

Nagel Karke R Square

Model Summary

\begin{tabular}{|c|c|c|c|}
\hline Step & $\begin{array}{c}-2 \text { Log } \\
\text { Likelihood }\end{array}$ & $\begin{array}{c}\text { Cox \& Snell } \\
\text { R Square }\end{array}$ & $\begin{array}{c}\text { Nagelkerke } \\
\text { R Square }\end{array}$ \\
\hline 1 & 263,179 & .259 & .347 \\
\hline
\end{tabular}

Berdasarkan Tabel 4.5. memberikan nilai Nagelkerke R Square sebesar 0,347. Hal ini berarti variabilitas variabel dependen yang dapat dijelaskan oleh variabilitas 
variabel independen sebesar 34,7\% sedangkan sisanya sebesar 66,3\% dijelaskan oleh variable lain yang tidak digunakan dalam penelitian ini

\subsection{Pembahasan}

Pengujian hipotesis menggunakan regresi logistik, yaitu untuk menguji pengaruh fee audit, tenure auditor, dan rotasi auditor terhadap kualitas audit. Pengujian signifikansi koefisien dari setiap variabel bebas menggunakan $p$-value (probability value) dengan tingkat signifikansi sebesar $10 \%$ (0.1). Apabila nilai signifikansi kurang dari 0.1 hipotesis diterima. Hasil pengujian hipotesis dalam penelitian ini disajikan sebagai berikut:

\begin{tabular}{|l|l|l|l|l|l|l|}
\hline & B & S.E. & $\begin{array}{l}\text { Wal } \\
\text { d }\end{array}$ & $\begin{array}{l}\text { D } \\
\mathrm{f}\end{array}$ & Sig. & $\begin{array}{l}\text { Exp } \\
\text { (B) }\end{array}$ \\
\hline $\begin{array}{l}\text { Fee } \\
\text { Audit }\end{array}$ & $\begin{array}{l}4 \\
35\end{array}$ &, 148 & $\begin{array}{l}8.6 \\
72\end{array}$ & 1 &, 003 & $\begin{array}{l}1,54 \\
5\end{array}$ \\
\hline $\begin{array}{l}\text { Audit } \\
\text { Tenure }\end{array}$ &, 0 &, 113 &, 65 & 1 &, 418 & $\begin{array}{l}1,09 \\
5\end{array}$ \\
\hline Step 1a & & & & & & \\
\hline $\begin{array}{l}\text { Rotasi } \\
\text { KAP }\end{array}$ &, 0 &, 586 &, 01 & 1 &, 909 & $\begin{array}{l}2,34 \\
3\end{array}$ \\
\hline $\begin{array}{l}\text { Constan } \\
\mathrm{t}\end{array}$ & $\begin{array}{l}- \\
19 \\
8 \\
44\end{array}$ & 3,17 & $\begin{array}{l}39, \\
118\end{array}$ & 1 &, 000 &, 000 \\
\hline
\end{tabular}

Dari pengujian persamaan regresi logistik tersebut tersebut, maka diperoleh model regresi logit sebagai berikut :

\section{$Y=-19,844+0,435 X 1+0,091 X 2+0,067 X 3+0,851 X 4$}

Berdasarkan persamaan garis regresi logit yang terbentuk dan nilai-nilai dari koefisien regresi masing-masing variabel bebas, maka besarnya nilai dari intercept dan nilai koefisien dari variabel bebas dapat diinterprestasikan. Interpretasi yang tepat untuk koefisien ini tentunya tergantung pada kemampuan menempatkan arti dari perbedaan antara dua logit. Oleh karenanya, dalam regresi logistik, pengukuran koefisien regresi logit menggunakan ukuran yang dikenal dengan nama odds ratio atau Exp (B). Dari hasil perhitungan analisis regresi maka interprestasi koefisien regresi dapat dijelaskan sebagai berikut:

1. Nilai intercept persamaan regresi diatas adalah sebesar $-19,844$ dengan nilai odds ratio sebesar 0,000 . Hal ini berarti peluang perusahaan mendapatkan audit yang berkualitas adalah sebesar 0,000 dibandingkan peluang perusahaan tidak mendapatkan audit yang berkualitas dengan asumsi semua variabel bebas bernilai 0 .

2. Nilai koefisien regresi variable fee audit adalah sebesar 0,435 dengan nilai odds ratio sebesar 1,545. Hal ini berarti apabila fee audit meningkat satu satuan maka peluang perusahaan perusahaan mendapatkan audit yang berkualitas akan meningkat sebesar 1,545 dengan asumsi variabel bebas lainnya dianggap konstan. 
3. Nilai koefisien regresi variable tenure audit adalah sebesar 0,091 dengan nilai odds ratio sebesar 1,095. Hal ini berarti apabila variable tenure audit perusahaan meningkat satu satuan maka peluang perusahaan perusahaan mendapatkan audit yang berkualitas akan meningkat sebesar 1,095 dengan asumsi variabel bebas lainnya dianggap konstan.

4. Nilai koefisien regresi variable pergantian KAP adalah sebesar 0,067 dengan nilai odds ratio sebesar 1,069. Hal ini berarti apabila variable tenure audit perusahaan meningkat satu satuan maka peluang perusahaan perusahaan mendapatkan audit yang berkualitas akan meningkat sebesar 1,069 dengan asumsi variabel bebas lainnya dianggap konstan.

Pengujian terhadap hipotesis pertama dilakukan melalui pengujian signifikansi koefisien regresi dari variabel fee audit. Hipotesis pertama penelitian ini menyatakan bahwa fee audit berpengaruh positif terhadap Kualitas Audit. Nilai koefisien regresi variabel audit tenure adalah 0,435 dengan nilai signifikansi sebesar 0,003 dan pada tingkat signifikansi $\alpha=5 \%$; maka koefisien regresi tersebut signifikan karena signifikansi 0,003 $<0,05$, maka dapat disimpulkan bahwa, fee audit berpengaruh positif signifikan pada kualitas audit sehingga Ha1 dapat didukung.

Pengujian terhadap hipotesis kedua dilakukan melalui pengujian signifikansi koefisien regresi dari variabel audit tenure. Hipotesis kedua penelitian ini menyatakan bahwa Audit Tenure berpengaruh negatif terhadap Kualitas Audit. Nilai koefisien regresi variabel audit tenure adalah 0,091 dengan nilai signifikansi sebesar 0,418 dan pada tingkat signifikansi $\alpha=5 \%$; maka koefisien regresi tersebut tidak signifikan karena signifikansi 0,418 >0,05, maka dapat disimpulkan bahwa, audit tenure tidak berpengaruh signifikan terhadap kualitas audit sehingga Ha2 tidak dapat didukung.

Pengujian terhadap hipotesis ketiga dilakukan melalui pengujian signifikansi koefisien regresi dari variabel rotasi KAP. Hipotesis ketiga penelitian ini menyatakan bahwa Rotasi KAP berpengaruh positif terhadap Kualitas Audit. Nilai koefisien regresi variabel rotasi KAP adalah 0,067 dengan nilai signifikansi sebesar 0,909 dan pada tingkat signifikansi $\alpha=5 \%$; maka koefisien regresi tersebut tidak signifikan karena signifikansi 0,909 >0,05, maka dapat disimpulkan bahwa, Rotasi KAP tidak berpengaruh signifikan terhadap Kualitas Audit sehingga Ha3 tidak dapat didukung.

Hasil penelitian menunjukkan fee audit berpengaruh positif signifikan terhadap kualitas audit. Semakin tinggi fee audit akan meningkatkan kualitas audit perusahaan. Teori agensi bertujuan untuk menjelaskan bagaimana pihak-pihak yang melakukan hubungan kontrak dapat meminimalisir biaya karena adanya informasi yang tidak simetris dan kondisi ketidakpastian.

Hasil penelitian membuktikan bahwa audit tenure tidak berpengaruh signifikan terhadap kualitas audit. Hal ini berarti bahwa besar kecilnya audit tenure tidak akan mempengaruhi kualitas audit perusahaan.

Adanya penolakan atas hipotesis 2 ini dikarenakan masa perikatan audit bukan patokan bahwa hasil audit akan berkualitas. Lamanya masa perikatan audit seharusnya kantor akuntan publik lebih mengerti kondisi perusahaan klien sehingga tau jika klien ingin memanipulasi laporan keuangan, tetapi karena masa perikatan yang lama juga kantor akuntan publik merasa percaya dengan klien sehingga tidak 
mengembangkan strategi prosedur audit yang digunakan dan menurunkan kualitas audit.

Adanya penolakan atas hipotesis 3 ini dikarenakan masa perikatan audit bukan patokan bahwa hasil audit akan berkualitas. Lamanya masa perikatan audit seharusnya kantor akuntan publik lebih mengerti kondisi perusahaan klien sehingga tau jika klien ingin memanipulasi laporan keuangan, tetapi karena masa perikatan yang lama juga kantor akuntan publik merasa percaya dengan klien sehingga tidak mengembangkan strategi prosedur audit yang digunakan dan menurunkan kualitas audit. Kemungkinan tidak berpengaruhnya variabel, bisa jadi disebabkan oleh keengganan pihak pelaku pasar untuk mengeksplorasi lebih jauh apakah auditor yang mengeluarkan opini pada laporan keuangan auditan benar-benar pernah mengalami rotasi atau tidak Hartadi (2012).

\section{PENUTUP}

\subsection{Kesimpulan}

Kesimpulan hasil penelitian ini adalah sebagai berikut :

1. Hasil penelitian menunjukkan fee audit berpengaruh positif signifikan terhadap kualitas audit. Semakin tinggi fee audit akan meningkatkan kualitas audit perusahaan.

2. Hasil penelitian membuktikan bahwa audit tenure tidak berpengaruh signifikan terhadap kualitas audit. Hal ini berarti bahwa besar kecilnya audit tenure tidak akan mempengaruhi kualitas audit perusahaan.

3. Hasil penelitian membuktikan bahwa rotasi KAP tidak berpengaruh signifikan terhadap kualitas audit. Hal ini berarti apabila perusahaan melakukan rotasi KAP maka tidak akan mempengaruhi kualitas audit perusahaan 


\section{DAFTAR PUSTAKA}

Abdul-Rahman, O. A., Benjamin, A. O., \& Olayinka, O. H. (2017). Effect of audit fees on audit quality: Evidence from cement manufacturing companies in Nigeria.

European Journal of Accounting, Auditing and Finance Research, 5(1), 6-17.

Arens, Alvin A., Elder, Randal J., and Beasley, Mark S. (2012). Auditing and assurance Services: An Integrated Approach, 14th edition. New Jearsey: Pearson Education, Inc.

Ardyana, Friska Tashia. 2017. FAKTOR-FAKTOR YANG MEMPENGARUHI KUALITAS AUDIT (Studi Empiris pada Kantor Akuntan Publik di Surakarta dan Yogyakarta.

Arens,Alvin A., Randal J. Elder., Mark S.Beasley.2001. Auditing and Assurance Services - An Integrated Approach. 9th Edition. Alih Bahasa Tim Dejacarta.Jilid 1.Prentice hall international,Inc.New York.

Chi, H. Y., \& Weng, T. C. (2014). Managerial legal liability and Big 4 auditor choice. Journal of Business Research, 67(9), 1857-1869.

De Angelo, L.E. 1981. Auditor Size and Audit Quality. Journal of Accounting \& Economic.

Djamil, N. (2000). Factors affecting audit quality in the public sector and some characteristics to increase it. Journal of Economics and Accounting STIE Nasional Banjarmasin.

Gammal, W,E. 2012. "Determinants of Audit Fees : Evidence From Lebanon.”Journal International Business Research Vol.5, No.11: 136-143.

Gultom dan Fitriany.2013."Pengaruh Tenure Audit dan Rotasi Auditor terhadap Kualitas Audit dengan Ukuran Kantor Akuntan Publik sebagai Variabel Moderasi".Makalah Simposium Nasional Akuntansi XVI Manado.

Handayani, Dewi. 2014. "Pengaruh Kompetensi ,Independensi, Workload Dan Spesialisasi Auditor Terhadap Kualitas Audit. (Studi Empiris Pada Auditor KAP Di Surakarta dan Yogyakarta). Skripsi. Universitas Muhammadiyah Surakarta.

Jackson, A. B., Moldrich, M., \& Roebuck, P. (2007). Mandatory audit firm rotation and audit quality. http://papers.ssrn.com/sol3/papers.cfm?abstract id=1000076

Kementrian Keuangan RI. Keputusan Menteri Keuangan Republik Indonesia Nomor 423/KMK.06/2002, Tentang Jasa Akuntan Publik.

Kementrian Keuangan RI. Keputusan Menteri Keuangan Republik Indonesia Nomor 359/KMK.06/2003, Tentang Jasa Akuntan Publik.

Kementrian Keuangan RI. Peraturan Menteri Keuangan Republik Indonesia Nomor 17/PMK.01/2008, Tentang Jasa Akuntan Publik.

Krissindiastuti, M., \& Rasmini, N. K. (2016). Faktor-Faktor yang Mempengaruhi Opini Audit Going Concern. E-Jurnal Akuntansi, 451-481.

Langgeng subur.https://finansial.bisnis.com/read/20180731/9/822382/pemerintah 
genjot-kualitas-audit.diakses pada 16 September 2019.

Loebbecke, A. A. (1996). Auditing. Jakarta, Indonesia: Salemba Empat

Mgbame, C.O.,Eragbhe, E, dan Osazuwa, N. 2012. "Audit Partner Tenure and Audit Quality: An Empirical Analysis." European Journal of Business and Management, Vol.4, No.7,pp.154-159.

Ninik Andriani dan Nursiam. 2017. PENGARUH FEE AUDIT, AUDIT TENURE, ROTASI AUDIT DAN REPUTASI AUDITOR TERHADAP KUALITAS AUDIT (Studi Empiris Pada Perusahaan Manufaktur yang Terdaftar di Bursa Efek Indonesia Tahun 2013-2015).

Permana, Klaudia Xary. (2012). "Pengaruh Masa Perikatan Audit dan Ukuran KAP Terhadap Kualitas Audit". Universitas Diponegoro Semarang. Skripsi.

Putra, I Gede Cahyadi. 2013. "Kualitas Audit Kantor Akuntan Publik di Bali Ditinjau dari Time Budget Pressure, Risiko Kesalahan, dan Kompleksitas Audit." Jurnal Ilmiah Akuntansi dan Humanika Jinah, Vol.2, No.2,pp.765-784.

Sinaga, Daut M.T. 2012. Analisis Pengaruh Audit Tenure, Ukuran KAP dan Ukuran Perusahaan Klien terhadap Kualitas Audit. Universitas Diponegoro, Semarang.

Siregar, et al.,. 2012. Audit Tenure, Auditor Rotation, and Audit Quality: The Case of Indonesia . Asian Journal of Business and Accounting. , Sylvia Veronica Siregar , Fitriany Amarullah, Arie Wibowo and Viska Anggraita 2012.

Tobi, B. A., Osasrere, A. O., \& Emmanuel, U. (2016). Auditor's independence and audit quality: A study of selected deposit money banks in Nigeria. International Journal of Finance and Accounting, 5(1), 13-21. https://doi.org/10.5923/j.ijfa.20160501.02

Winda dan Sofie. 2014." Pengaruh Kompetensi, Independensi, Tekanan Waktu, dan Etika Auditor Terhadap Kualitas Audit." e-Journal Akuntansi Fakultas Ekonomi Universitas Trisakti Volume. 1 Nomor. 2 September 2014 Hal. 4967.

Yuniarti, R. (2011). Audit firm size, audit fee and audit quality. Presentation, American. 
Halaman ini sengaja dikosongkan 